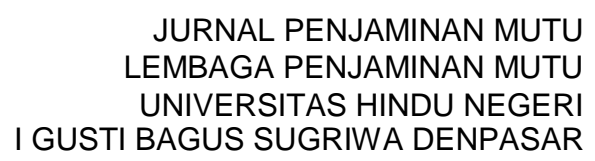

\title{
EFEKTIVTIAS PEMBELAJARAN DARING PADA PENDIDIKAN VOKASI
}

\author{
Oleh \\ Ketut Nurhayanti ${ }^{1}$, I.G.A Astri Pramitari ${ }^{2}$, I Made Budiada ${ }^{3}$ \\ ${ }^{12) 3)}$ Politeknik Negeri Bali \\ nurhayantiketut@gmail.com ${ }^{1}$, astripramitari@pnb.ac.id ${ }^{2}$, madebudiada@pnb.ac.id ${ }^{3}$
}

diterima 24 Juli 2021, direvisi 15 Agustus 2021, diterbitkan 31 Agustus 2021

\begin{abstract}
This study aims to describe the effectiveness of online learning in vocational colleges in Hindu theory courses and electrical installation practices. Assessment indicators are student learning outcomes, learning completion, student interests and motivations as well as attractive learning experiences experienced by students during online learning. Quality research with qualitative descriptive research approach is used in this study. Data collection techniques using questionnaires in the form of essays are disseminated through the google form platform and interviews conducted with google meet. Respondents numbered 50 students. The results of online learning research are effective if reviewed from indicators of the value of learning outcomes and complete materials but are not effective if reviewed from behavior changes. Indicators of attractive learning experience will be fun assuming the media used and lecturers can package materials in an interesting, interest and motivational learning students more to the obligation to get value and no other learning alternatives except online.
\end{abstract}

\section{Keywords : Effectiveness of Online learning, Vocational Education}

\section{PENDAHULUAN}

Pendidikan vokasi menurut Undangundang Sistem Pendidikan Nasional No. 20 Tahun 2003 adalah pendidikan pada jenjang perguruan tinggi yang bertujuan untuk menciptakan sumber daya manusia dengan kompetensi keahlian terapan tertentu setara dengan program sarjana. Winangun 2017 menyatakan bahwa perguruan tinggi yang bergerak pada bidang vokasi selalu dinamis, berinovasi dan selalu merevitalisasi kurikulum sesuai dengan kebutuhan dunia kerja, dunia industri serta beradaptasi dengan perkembangan teknologi. Sehingga Pavlova 2009 menyatakan pendidikan vokasi merupakan lembaga pendidikan dengan tujuan utama mempersiapkan, membentuk sumber daya manusia yang siap kerja dengan menggunakan pendekatan pendidikan berbasis kompetensi. 
Peran teknologi pendidikan dalam proses pembelajaran sangatlah penting Salsabila et al, 2020 peran teknologi pendidikan sebagai alat dukung desain pengetahuan, sarana informasi bagi peserta didik, memfasilitasi peserta didik berdiskusi pada saat proses pembelajaran, meningkatkan efektivitas dan efesiensi pembelajaran, dan alat bantu untuk mencapai tujuan pendidikan. Perkembangan teknologi terutama pada bidang pendidikan memberikan ide untuk mencetuskan konsep pembelajaran e-learning dan blanded learning. Blanded learning yaitu memadukan antara pertemuan tatap muka dengan pertemuan secara online. Pendidikan vokasi yang notabene mengimplementasikan mata kuliah praktek lebih banyak dibandingkan dengan mata kuliah teori secara otomatis tidak bisa menerapkan konsep pembelajaran $e$ learning secara menyeluruh, karena diperlukan pertemuan secara tatap muka untuk memberikan materi praktikum. Mewabahnya virus corona atau covid 19 di Indonesia pada awal tahun 2020 menjadikan pembelajaran e-learning menjadi satu-satunya cara agar pembelajaran di sekolah maupun perguruan tinggi terus berlangsung, pembelajaran ini dikenal dengan pembelajaran secara daring (dalam jaringan).

Ketidakpastian akan kapan berakhirnya pandemi covid 19 pada masyarakat, berimplikasi pada tidak tentu berakhirnya kebijakan penerapan pembelajaran daring di sekolah maupun perguruan tinggi. Pemberlakuan sistem pembelajaran daring sudah dalam kurun waktu tiga semester atau satu setengah tahun, walaupun tidak ada pilihan lain akan tetapi setiap kebijakan tentunya memiiki dampak negatif maupun positif, dan pembelajaran daring tidak terlepas permasalahan di dalamnya. Sehingga, sangat dipandang perlu untuk selalu melaksanakan asesmen pembelajaran daring dengan tujuan mengkaji efektivitas pembelajaran yang sudah dilaksanakan. Berbicara efektivtias pembelajaran maka tidak terlepas dari berbagai indikator penilaian yang menyatakan bahwa pembelajaran tersebut dinyatakan efektif, terlebih bahwa pada jenjang pendidikan vokasi output pembelajaran adalah kompetensi peserta didik berdasarkan pada bidang keahliannya.

\section{HASIL DAN PEMBAHASAN}

Metode penelitian menggunakan penelitian deskriptif kualitatif dengan teknik pengumpulan data menggunakan kuisioner yang disebarkan melalui google meet kepada mahasiswa Politeknik Negeri Bali jurusan akuntansi dan jurusan teknik elektro, serta buku dan hasil penelitian berbagai artikel. Penelitian terkait dengan pembelajaran daring di masa pandemi sudah banyak sekali dilakukan. Rosali, Ely Satiyasih (2020) menyatakan bahwa penerapan pembelajaran daring secara menyeluruh dalam kategori lancar akan tetapi kurang ideal sehingga memerlukan tinjauan lebih lanjut lagi untuk memnciptakan model pembelajaran daring yang variatif dalam waktu jangka panjang. Senada dengan hal tersebut Widiyono, Aan (2020) mengemukakan bahwa penerapan pembelajaran daring kurang efektif ditinjau dari tingkat kesulitan pemahaman mahasiswa terhadap materi dan terlalu banyaknya tugas yang diberikan oleh dosen. beberapa hasil penelitian tersebut memang tidak bisa membuktikan secara menyeluruh bahwa penerapan pembelajaran daring tidak efektif akan tetapi, tentu saja memerlukan penelitianpenelitian selanjutnya dengan berbagai perspektif dan sudut pandang untuk mengkaji efektivitas pembelajaran daring pada lembaga pendidikan di masa pandemi saat ini.

Falah, Nailul (2014) Pembelajaran dikatakan efektif apabila dalam proses pembelajaran setiap elemen berfungsi secara keseluruhan, peserta merasa senang, puas dengan hasil pembelajaran, membawa kesan, sarana/fasilitas memadai, materi dan metode affordable, pembimbing profesional. Tinjauan utama efektivitas pembelajaran adalah outputnya, yaitu kompetensi peserta didik. Efektivitas pembelajaran daring pada penelitian ini akan dikaji dari berbagai indikator penilaian, capaian hasil belajar, minat dan motivasi, serta pengalaman belajar atraktif. Penekanan penelitian ini dilakukan di lembaga pendidikan vokasi memberikan suatu argumen output pendidikan vokasi 
adalah kompetensi peserta didik untuk memiliki keahlian pada bidang tertentu, dengan mengikuti proses perkuliahan lebih banyak praktek dibandingkan teori, masa pandemi saat ini yang mengharuskan pembelajaran dilaksanakan secara daring memberikan tantangan tersendiri bagi lembaga pendidikan bidang vokasi untuk tetap mempertahankan mutu output peserta didiknya. Sehingga dipandang perlu melakukan berbagai kajian mengenai efektivitas pembelajaran daring pendidikan vokasi. Efektivitas pembelajaran daring pada pendidikan vokasi di Politeknik Negeri Bali akan dikaji berdasarkan pada indikator capaian hasil belajar, minat dan motivasi belajar serta pengalaman belajar yang atraktif.

\section{a. Capaian hasil belajar}

Capaian hasil belajar pada pembelajaran daring di lembaga pendidikan vokasi Politeknik Negeri Bali dengan jumlah responden 50 Orang mahasiswa jurusan akuntansi dan teknik elektro, aspek penilaian kepuasan mahasiswa terhadap nilai yang mereka peroleh dan ketuntasan nilai minimal. capaian hasil belajar dengan aspek penilaian kepuasan mahasiswa terhadap nilai yang mereka peroleh $80 \%$ responden menyatakan bahwa mereka tidak puas terhadap nilai yang mereka peroleh dengan asumsi bahwa mereka merasa akan mendapatkan nilai yang lebih baik jika pembelajaran dilaksanakan secara luring. Pembelajaran daring memberikan dampak tinginya tingkat kesulitan pemahaman akan materi yang disampaikan oleh dosen, karena keterbatasan akan paket kuota, gangguan jaringan, atau tidak maksimalnya diskusi dua arah pada saat pembelajaran berlangsung Prasetya dan Harjanto (2020), Tingkat kepuasan mahasiswa merupakan salah satu tolak ukur mutu e-learning. Tingkat kepuasan mahasiswa pengguna e-learning bisa menunjukan mahasiswa menikmati proses pembelajaran online. Hasminidiarty (2020) ketidakpuasan mahasiswa terhadap nilai yang mereka peroleh akan menjadi salah satu motivasi untuk tekun belajar. Dari hasil penelitian ini diharapkan ada kajian lebih mendalam lagi mengenai faktor-faktor kepuasaan mahasiswa terhadap nilai yang mereka peroleh selama pembelajaran daring sehingga berkontribusi untuk perbaikan model pembelajaran daring yang sudah berjalan selama ini.

Hasil penelitian dari indikator capaian hasil belajar $14 \%$ mendapatkan nilai A (81100), $22 \%$ mendapatkan nilai $\mathrm{AB}$ (76-80) dan $64 \%$ mendapatkan nilai B (65-75). Terkait dengan hasil belajar pada aspek ketuntasan nilai minimal menunjukan tuntas dengan nilai ketuntasan (nilai $\geq 60$ ), hal ini sesuai dengan pendapat nirfayanti (2019) bahwa nilai ketuntasan belajar sebesar 70. Hal ini memang akan kotradiktif dengan hasil kepuasaan mahasiswa terhadap nilai yang mereka peroleh, walaupun masuk dalam kategori nilai tuntas akan tetapi muncul rasa tidak puas mahasiswa dengan anggapan bahwa mereka akan mendapatkan nilai yang lebih maksimal jika pembelajaran berlangsung secara langsung, tentu saja hal ini perlu penelitian atau kajian lebih mendalam lagi terkait dengan asumsi ini.

\section{b. Minat dan Motivasi Mahasiswa}

Et al Cahyani (2020) Iklim belajar yang diciptakan pembelajaran daring turut mempengaruhi motivasi belajar peserta didik. Peter Salim dan Yenny Salim (1991) Motivasi belajar adalah variabel yang terdiri dari dua kata yaitu motivasi dan belajar, yang keduanya memiliki arti tersendiri. Jika membahas mengenai motivasi, sering kali disandingkan dengan kata motif. Sesuai dengan penelusuran peneliti, motif dapat diartikan sebagai gerak atau sesuatu yang mendorong individu untuk bergerak. Motivasi belajar mahasiswa mengikuti pembelajaran daring masa pandemi covid 19 pada pendidikan vokasi. $95 \%$ respoden memberikan argumen terkait dengan minat dan motivasi mereka mengikuti pembejaran daring pada mata kuliah teori maupun praktek yaitu:

1. Memenuhi kewajiban sks dan mendapatkan nilai

2. Keadaan ekonomi yang sulit sehingga mereka tidak mau menyia-nyiakan kuliah mereka walaupun secara daring 
3. Menambah wawasan tentang agama Hindu, aturan-aturan agama, menambah wawasan mengenai kelistrikan

4. Karena pembelajaran daring merupakan satu-satunya cara mereka berinteraksi dengan dosen dan mendapatkan pengathuan dari dosen.

5. Tidak memiliki motivasi apapun

Marilyn K. Gowing dalam (Fransisco: Jossey-Bass (2001) ada empat poin aspekaspek motivasi belajar, adanya dorongan mencapai sesuatu, komitmen, mengeksplor ide atau inisiatif, dan rasa optimis, Frandsen menyatakan aspek motivasi karena rasa ingin tahu, kreativitas, keinginan mendapatkan simpati, memperbaiki kegagalan pembelajaran sebelumnya, memiliki rasa aman karena menguasai materi. hasil penelitian mengenai minat dan motivasi mahasiswa mengikuti pembelajaran daring pada mata kuliah agama Hindu dan Instalasi listrik di Politeknik Negeri Bali jika dikaji dari aspek-aspek motivasi menurut Marilyn K. Gowing dan Frandsen cenderung pada apsek komitmen menjalankan kewajiban sebagai mahasiswa mengikuti perkuliahan karena berkorelasi terhadap nilai yang akan mereka peroleh, rasa ingin tahu terhadap materi. tidak adanya motivasi untuk mengeksplor kreatifitas/ide mereka karena keterbatasan akan ruang dan waktu, ada 5\% responden menyatakan bahwa mereka tidak memiliki motivasi apapun dalam pembelajaran daring ini. Mulyono, Wahyu Dwi (2020) mahasiswa mengikuti semua pembelajaran daring sebagai keharusan dan tuntutan belajar, tetapi merasa kurang nyaman dan lebih memilih pada pembelajaran tatap muka. Cahyani, Adhetya et al (2020) menurunnya motivasi peserta didik disebabkan tidak adanya interaksi langsung dengan tenaga pendidik dimana tenaga pendidik bisa memberikan hadiah pujian, menegur, menghukum secara langsung.

\section{c. Pengalaman Belajar Atraktif}

Pembelajaran merupakan proses peserta didik mendapatkan keahlian, perubahan perilaku, menambah wawasan, menumbuhkan kreatifvitas. Pada proses pembelajaran peserta didik akan memperoleh pengalaman belajar yang berbeda-beda antara satu sama lainnya, Tyler (1973:63) pengalaman belajar berbeda dengan konten materi pembelajaran atau kegiatan yang dilakukan oleh guru karena pengalaman belajar mengacu kepada interaksi antara pelajar dengan kondisi eksternal lingkungan dimana dia belajar. Pengalaman belajar yang menarik, menyenangkan, indah, mempesona, penuh dengan kreativitas, tidak terkesan membosankan atau biasa disebut dengan pengalaman belajar yang atraktif lebih banyak ditemukan pada proses pembelajaran yang mengarah kepada praktek, belajar di ruang terbuka, serta penggunaan media pembelajaran yang variatif. Fallah, Nailul (2014), out bound sebagai salah satu metode pembelajaran yang memberikan kesan menarik karena mampu memberikan pengalaman langsung kepada mahasiswa. Ini akan menjadi pekerjaan yang berat jika pembelajaran dilaksanakan secara daring yang notabene mahasiswa belajar dari rumah masing-masing, tidak bertatap muka langsung dengan teman dan dosen, terlebih pada mata kuliah praktek mahahsiswa jurusan teknik, mahasiswa tidak bisa melihat, mengamati, memegang secara langsung alat-alat yang digunakan karena hanya melalui video tutorial yang diberikan oleh dosen.

Pengalaman belajar atraktif pembelajaran daring mata kuliah teori dan praktek pada pendidikan vokasi menekankan pada kreativitas dosen dalam menggunakan media pembelajaran yang kekinian, mulai dari zoom, google meet, video tutorial, voice note, akan tetapi penggunaan media pembelajaran tidak mampu untuk menggantikan pengalaman belajar yang mereka peroleh pada pertemuan praktikum jika dilaksanakan secara langsung, tatap muka karena mereka dapat mengamati, memegang, mempraktekan secara langsung alat-alat yang digunakan. Syafri dan Kulsum melakukan penelitian pada tahun 2021 dengan subjek peserta didik jenjang Sekolah Menengah Pertama dan ditemukan bahwa media sosial Tiktok mampu memberikan pengalaman atraktif bagi peserta 
didik pada pembelajaran daring di masa pandemi. Akan tetapi jika dikaji lebih mendalam bahwa media sosial akan menjadi media pembelajaran yang menarik bagi peserta didik pada mata kuliah teori, akan berbeda kondisinya jika diterapkan pada mata kuliah praktek, karena cenderung akan sama seperti penggunakan video tutorial hanya memberikan pengalaman belajar menarik akan tetapi tidak pengalaman belajar secara langsung.

\section{KESIMPULAN}

Efektivitas pembelajaran daring pada pendidikan vokasi jika dikaji dari indikator capaian hasil belajar, minat dan motivasi mahasiswa serta pengalaman belajar yang atraktif maka dapat disimpulkan bahwa pembelajaran dinyatakan efektif jika dikaji dari indikator capaian hasil belajar dengan asumsi bahwa nilai yang didapatkan mahasiswa sudah memenuhi nilai standar minimum, akan berbanding terbalik jika dikaji dari aspek kepuasaan mahasiswa terhadap nilai yang mereka peroleh yang mana mahasiswa tidak puas terhadap nilai yang mereka peroleh. Minat dan motivasi mahasiswa tertumpu pada aspek kewajiban mereka untuk mengikuti perkuliahan karena jika tidak mengikuti maka mereka tidak akan mendapatkan nilai, motivasi untuk mendapatkan tambahan wawasan dari dosen tidak menjadi faktor utama mereka mengikuti perkuliahan daring, bahkan ada yang memberikan pernyataan bahwa mereka tidak memiliki motivasi apapun dalam pembelajaran daring sehingga mereka terkesan hanya sekedar mengikuti perkuliahan. Fenomena ini sepertinya memiliki korelasi terhadap pengalaman belajar atraktif yang mereka dapatkan pada saat pembelajaran daring, yang cenderung membosankan, terlebih jika dosen tidak menggunakan media pembelajaran yang variatif, dan tidak bisa praktek secara langsung pendidikan vokasi yang notabene memiliki lebih banyak mata kuliah praktek dibandingkan teori akan memiliki banyak sekali kendala jika harus terus melaksanakan pembelajaran secara daring.

\section{DAFTAR PUSTAKA}

Aktivitas dan Pengalaman Belajar ivonyerniwaty (wordpress.com) di akses pada tanggal 17 Juli 2021

Cahyani, Adhetya., Listiana, Iin Diah, Larasati, Sari Puteri Deta. 2020. Motivasi Belajar Siswa SMA pada Pembelajaran Daring di Masa Pandemi Covid-19. Jurnal Pendidikan Islam

Volume 3 No. 01 2020, p. 123-140.

Falah, Nailul. 2014. Efektivitas Out Bound Sebagai Metode Pembelajaran (Studi Pada Out Bound Mahasiswa Jurusan Bki Fakultas Dakwah Dan Komunikasi Uin Sunan Kalijaga Yogyakarta. Jurnal Hisbah, Vol. 11, No. 1, Juni 2014.

Hasminidiarty. 2015. Faktor-Faktor Yang Berkaitan Dengan Prestasi Belajar Mahasiswa. Jurnal Ilmiah Universitas Batanghari Jambi Vol.15 No.3 Tahun 2015.

Kuntang, Winangun. 2017. Pendidikan Vokasi Sebagai Pondasi Bangsa Menghadapi Globalisasi. Jurnal Taman Vokasi Vol. 5, No. 1, Juni 2017

Marilyn K. Gowing "Measurement of Individual Emotional Competence" dalam Daniel Goleman, Cary Cherniss (ed.). The emotionally intelligent workplace: How to select for, measure, and improve emotional intelligence in individuals, groups, and organizations. (Fransisco: JosseyBass, 2001

Mulyono, Wahyu Dwi. 2020. Respon Mahasiswa Terhadap Pembelajaran Daring Pada Masa Pandemi Covid-19. STEAM Engineering (Journal of Science, Technology, Education And Mechanical Engineering) Volume 2, Nomor 1

Pavlova, M. 2009. Technology and vocational education for sustainable development:

Empowering individuals for the future. Australia: Springer. 
Peter Salim dan Yenny Salim, Kamus Besar Bahasa Indonesia Kontemporer (Jakarta: Modern English, 1991).997

Prasetya, Tri Adi dan Harjanto, Chrisna Tri . 2020. Pengaruh Mutu Pembelajaran Online Dan Tingkat Kepuasan Mahasiswa Terhadap Hasil Belajar Saat Pandemi Covid19. Jurnal Pendidikan Teknologi dan Kejuruan Vol. 17, No. 2, Juli 2020

Rosali, Ely Satiyasih. 2020. Aktifitas Pembelajaran Daring Pada Masa Pandemi Covid-19 Di Jurusan Pendidikan Geografi Universitas Siliwangi Tasikmalaya. Geography Science Education Journal (GEOSEE) Volume 1 Nomor 1 Bulan Juni Tahun 2020 .

Salsabila, Unik Hanifah., Sari, Lailli Irna., Lathif, Khusna Haibati., Lestari, Ayu
Puji., Ayuning, Asyharinur. 2020. Peran Teknologi Dalam Pembelajaran Di Masa Pandemicovid-19. AlMutharahah: Jurnal Penelitian dan Kajian Sosial Keagamaan Vol. 17 No. 2. Juli-Desember 2020

Syafri, Elsa Putri dan Kulsum, Umi. 2021. TikTok; Media Pembelajaran Alternatif dan Atraktif pada Pelajaran PPKn Selama Pandemi di SMP Negeri 2 Mertoyudan Ermisah. SEMINAR NASIONAL Dinamika Informatika 2021 Universitas PGRI Yogyakarta.

Widiyono, Aan. 2020. Efektifitas Perkuliahan Daring (Online) pada Mahasiswa PGSD

di Saat Pandemi Covid 19. Jurnal Pendidikan, Vol. 8, No. 2, Tahun 2020 